Int. J. Dev. Biol. 57: 577-586 (2013)

doi: $10.1387 / \mathrm{ijdb} .130239 \mathrm{pr}$

\title{
Transformation of leguminous plants to study symbiotic interactions
}

\author{
ANELIA IANTCHEVA ${ }^{1}$, KIRANKUMAR S. MYSORE ${ }^{2}$ and PASCAL RATET ${ }^{*, 3}$ \\ ${ }^{1}$ AgroBiolnstitute, Sofia, Bulgaria, ${ }^{2}$ Plant Biology Division, The Samuel Roberts Noble Foundation, OK, USA and \\ ${ }^{3}$ Institut des Sciences Végétales, Centre National de Recherche Scientifique, Gif sur Yvette, France
}

\begin{abstract}
Legume plants are important in agriculture because they represent an important source of protein for human and animal consumption. This high protein content results from their capacity to use atmospheric nitrogen for their nutrition as a consequence of their symbiotic interaction with rhizobia. Understanding this interaction at the molecular level is a prerequisite for its better use in agriculture and for the long term objective of its transfer to other crops. Agrobacterium-mediated transformation is a tool of choice for studying this interaction and for unraveling the function of the different genes discovered through classical genetic approaches. However, legume plants are often recalcitrant to regeneration and transformation. This paper describes the technology developments (regeneration, transformation, insertion mutagenesis) related to Agrobacterium transformations that were established in the legume plants, as well as different examples of the technology developments or gene discoveries resulting from these studies.
\end{abstract}

KEY WORDS: legume plant, agrobacterium, rhizobium, transformation, symbiosis

\section{Legumes and their importance}

Amongst the mineral nutrients required by plants, nitrogen is the most important but its availability is unfortunately low in most soils. The intensive use of industrial nitrogen fertilizers in modern agriculture in the last 50 years has allowed the development of very productive crops, but their intensive use also resulted in eutrophication of continental waters including some areas in Europe. There is thus a strong need to reduce application of chemical nitrogen fertilizers and improve alternative nitrogen inputs (Graham and Vance 2003; Ferguson et al., 2010) in agriculture. A key contribution of legumes to sustainable agriculture and nitrogen cycle is their ability to fix atmospheric nitrogen in most agricultural ecosystems. They form specialized organs, the root nodules, in association with specific soil bacteria called rhizobia (including the genera Azorhizobium, Allorhizobium, Bradyrhizobium, Mesorhizobium, Rhizobium and Sinorhizobium). In these organs the bacteria differentiate into a form called the bacteroids and catalyze the reduction of atmospheric nitrogen gas $\left(\mathrm{N}_{2}\right)$ into ammonia using the nitrogenase enzyme complex. This process is commonly referred as "symbiotic nitrogen fixation". Annually the legume-rhizobia symbiosis produces around 200 million tons of nitrogen (Graham and Vance 2003) to the host plant thus reducing the need for nitrogen fertilizers. Members of the family Leguminosae are major crops used for human food, animal feed, and vegetable oil. They represent the third largest group of angiosperms and are the second largest group of food and feed crops grown worldwide. These plants are cultivated on $12-15 \%$ of available arable land and are responsible for more than $25 \%$ of the world's primary crop production. Around 250 million tons of grain legumes are produced annually world-wide. The ability of legumes to enter into symbiosis with nitrogen-fixing rhizobia provides them with a unique advantage compared to other plant species. For this reason legumes are called "green manure" and they are used in common farming practice as an intercrop or to rotate crop species, using legumes such as clover or alfalfa in the rotation. This rotation is a process that dramatically improves the organic content of the soil and for this reason improvement of the agricultural capacities of the legumes is always a goal for researchers in addition to the hope that one day this symbiotic capacity could be transferred to other non-leguminous crops (Charpentier and Oldroyd 2010).

\section{The legume-rhizobia symbiotic interaction}

The first step of the symbiotic interaction starts with the exudation of flavonoids (phenolics compounds) into the rhizosphere by the

Abbreviations used in this paper: AM, arbuscular mycorrhiza; N2, nitrogen gas; NF, Nod factor; TDZ, thidiazuron; T-DNA, agrobacterium tranfered DNA.

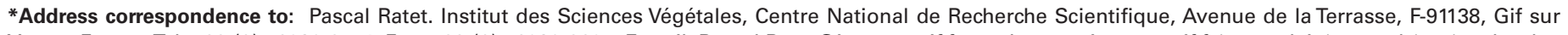

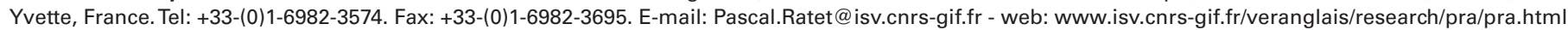



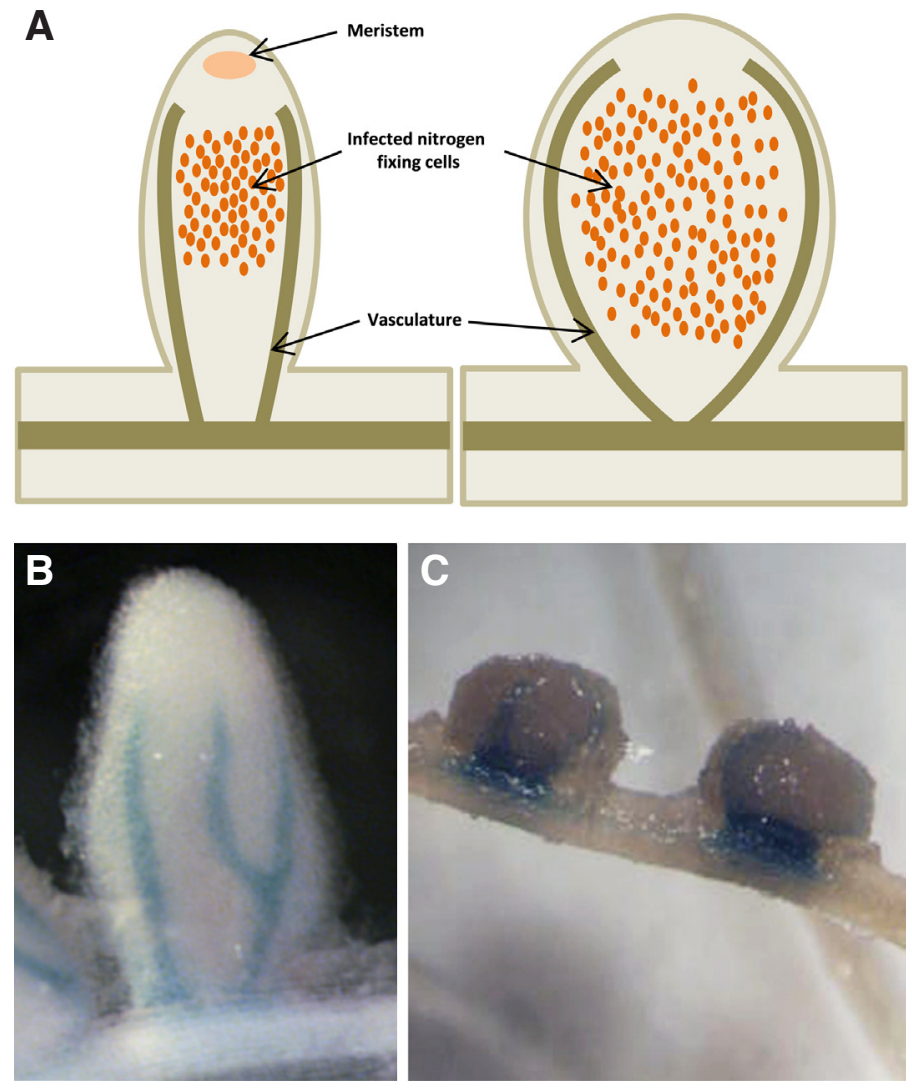

Fig. 1. Indeterminate and determinated nodules. (A) Schematic representation of the indeterminate (left) and determinated (right) nodules. The meristem position is represented by an orange oval in apical position. The infected cells in which nitrogen fixation takes place are represented by orange dots. (B) An indeterminated nodule expressing a nodule vascular tissue specific GUS fusion. (C) A determinated nodule expressing a cyclin F box promoter-GUS fusion at the base of the nodule and in the vascular tissues.

host plant roots. The specific flavonoid composition of the exudate determines the rhizobia species attracted. With the exception of rhizobium species NGR 234, which is able to colonize about 112 species, rhizobia are generally able to establish symbiosis with only few legumes. This attraction of specific rhizobia to the roots of host legume leads to the activation of bacterial nod genes and production and secretion of specific lipochito-oligosaccharides called Nod Factors (NFs) (Ferguson et al., 2010; Oldroyd et al., 2011) that are necessary for the bacterial invasion and the nodule organogenesis. The NFs are composed of an oligosaccharide backbone of $N$-acetyl-D-glucosamine units with a fatty acyl group attached to the non-reducing sugar. Specific modifications of this backbone happen in different rhizobium strains that define the specificity required for the plant bacterial recognition. In the rhizosphere, rhizobia attach to root-hair tips, initiate root hair deformation and curling and penetrate the root hair via a structure called the infection thread. This structure allows the symbiotic bacteria to reach the cortical cells of host plant. Increasing concentration of NF leads to mitotic activation of cortical cells in the root and starts the development of the nodule primordium. The infection thread grows towards the newly induced dividing cells and bacteria are released into an infection droplet in the host cell cytoplasm, forming an organelle like structure called the symbiosome. In the symbiosome, bacteria differentiate into bacteroids. In fully developed mature nodules, atmospheric $\mathrm{N}_{2}$ is reduced into ammonia by bacteroids and subsequently assimilated by the plant (Ferguson et al., 2010; Oldroyd et al., 2011).

Legume nodules are of the determinate or indeterminate type (Fig. 1A). There are three main differences between these two nodule types: the site of initial internal cell division, the lifetime of meristematic cells and the shape of the mature nodules. Indeterminate nodules are characterized with initial anticlinal division of inner cortex and periclinal divisions in endodermis and pericycle, leading to the formation of nodule primordia. Their persistent meristem divides continuously giving rise to new nodule cells and thus results in nodules with elongated shape. Legume species like Medicago sativa (alfalfa), Trifolium repens (clover), Pisum sativum (pea) and the model legume Medicago truncatula form indeterminate nodules. Determinate nodules are characterized by their round shape and lacks persistent meristem that results in the absence of developmental gradient. The initial cell division occurs sub-epidermally in the outer cortex. Legumes that form determinate nodules include Glycine max (soybean), Phaseolus vulgaris (common bean), and Lotus japonicus. M. truncatula and $L$. japonicus are used as model legumes to study indeterminate and determinate types of nodules, respectively (Handberg and Stougaard, 1992; Stiller et al., 1997).

In this review we discuss about various protocols available for legume regeneration and transformation. In addition, we will also describe how transformation technology has helped in deciphering some of the molecular events that allow legume plants to establish symbiosis with rhizobia.

\section{Legume regeneration and transformation}

The main component of most system biology approaches is a high-throughput regeneration/transformation system to decipher gene function. Transformation offers strategies for overexpressing or suppressing endogenous genes as well as expressing various gene fusions thus understanding their biological role during plant development. Large scale accumulation of data from "omics" platform in legumes necessitates the development of transformation protocols for rapid in vitro and in vivo investigation of functions and subcellular localization of the target genes. In addition to understanding gene function legume transformation also provides possibilities for crop improvement. For example, transgenic soybean is being widely cultivated in North and South America (Yamada et al., 2012).

Legume in vitro regeneration which has long been an obligatory step for transgenic production is still a challenge for plant scientists, thus making many legumes recalcitrant to efficient Agrobacterium tumefaciens-mediated plant transformation. However, the extensive use of the model legume plants like $M$. truncatula and $L$. japonicus for molecular studies has favoured the development of efficient regeneration and Agrobacterium-mediated transformation protocols for these two plant species. Agrobacterium-mediated transformation protocols rely on the availability of highly totipotent cells (targets for the transformation events), specific genotypes and proper selection of transformed tissue followed by 4 to 6 months of tissue culture.

In vitro regeneration of legumes is based on direct organogenesis, indirect organogenesis or somatic embryogenesis (Fig. 2) starting with different plant explants. Successful regeneration is 
accomplished by determination of species-specific parameters like explant source, plant genotype and media components. The somatic embryogenesis approach has been favoured because each event of regeneration is supposed to be derived from one cell and chromosomal rearrangements are less frequent (Arcioni et al., 1989). In the legume crops like alfalfa and red clover (Trifolium pratense) different dominant genes are thought to be involved in the control of somatic embryogenesis (McLean and Nowak, 1988; Reisch and Bingam, 1980). Dramatic improvement of embryogenic capacity has been observed after several cycles of recurrent selection mainly in the Medicago genus. Using this approach, lines with high embryogenic capacity were selected in M. sativa Rengelander (Atanassov and Brown, 1984), M. sativa Regen-SY (Samac et al., 2004), M. varia A2 (Deak et al., 1986), M. sativa R4 (Barbulova et al., 2002), M. falcata47/1/150 (Denchev et al., 1991), M. truncatula cv. R108-1 (Hoffman et al., 1997), M. truncatula cv. Jemalong 2HA (Nolan et al., 1989) and M. truncatula cv.Jemalong M9-10a (Araujo et al., 2004). It has been shown in Medicago (Rakocevic et al., 2009) and in Lotus (Madsen et al., 2005; Fukai etal., 2008; Fukai et
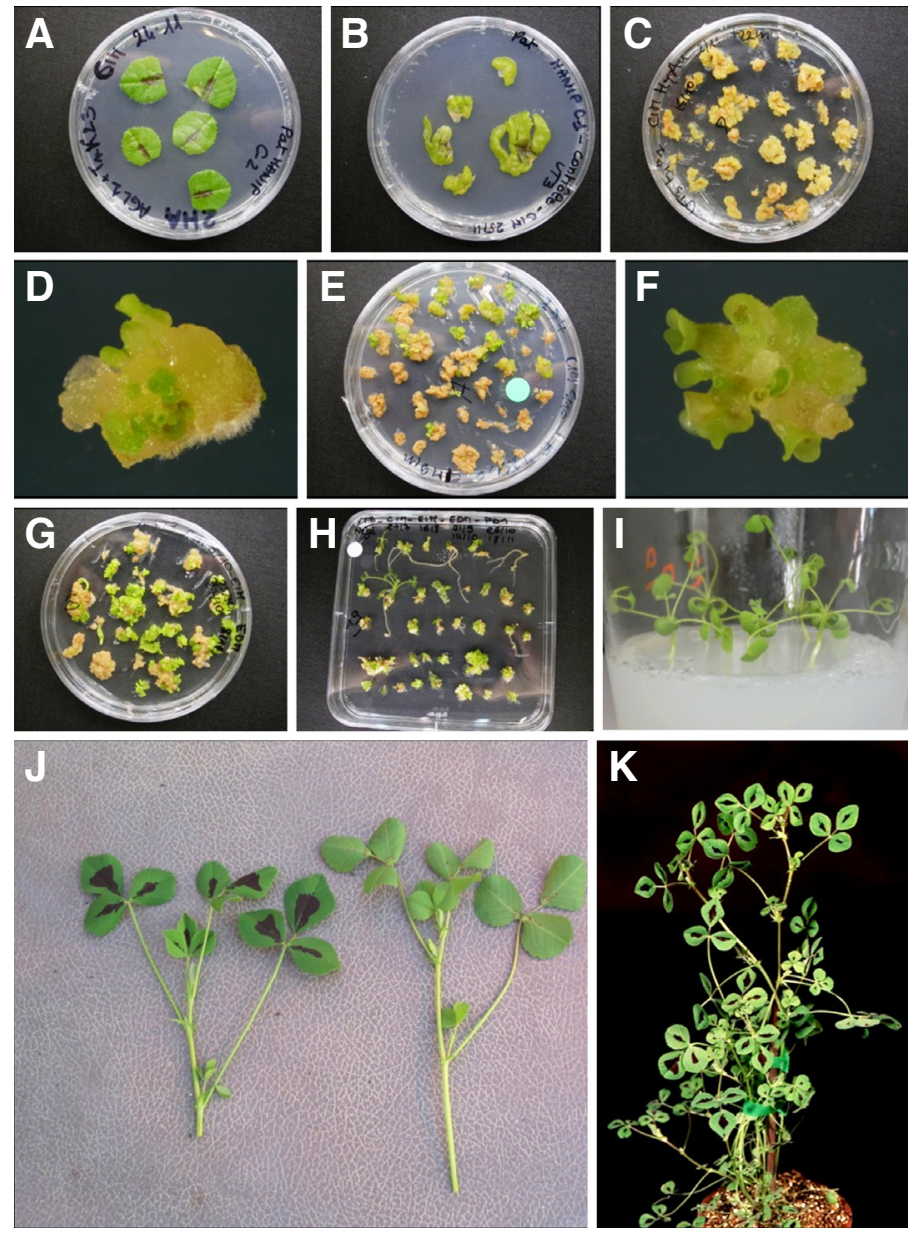

Fig. 2. Regeneration of Medicago plants using in vitro somatic embryogenesis. Leaf explants $(\mathbf{A})$ are placed on callus inducing medium (B) in order to induce embryogenesis (C). Embryos (D-F) are differentiating on hormone free medium in plantlets $(\mathbf{G})$ that are placed on rooting medium (H) and allow to develop in true plantlets (I). These are later adapted and transferred in the green house for further development (J) and seed production (K). In panel $\mathrm{J}$ the plant in the left is M. truncatula ssp truncatula Jemalong and the plant in the right is M. truncatula ssp tricycla $R 108$. al., 2012) that in vitro regeneration activates endogenous retroelements. We can therefore postulate that these recurrent selections have resulted in chromatin modification (epigenetic modifications) and/or insertion of new copies of endogenous elements that are deregulating genes that act as negative regulators of embryogenesis (Srinivasan et al., 2007). These highly embryogenic lines can then be considered as mutant lines.

For M. truncatula, direct regeneration as well as somatic embryogenesis protocols are well described (Cosson et al., 2006; Wright et al., 2006; Crane et al., 2006, lantcheva et al., 2001, Chabaud et al., 1996; Zhou et al., 2004). It should be noted that each protocol was developed for a specific line and may not be applicable to the whole species. For L. japonicus cv. Gifu, regeneration and stable Agrobacterium-mediated transformation protocols, mainly based on the use of hypocotyl explants, were develop by Handberg and Stougaard (1992) and improved by Stiller et al. (1997) who also established an $A$. rhizogenes hairy root transformation method.

Somatic embryogenesis in legumes is affected by exogenously supplied auxin, which plays important role in somatic embryo induction and development. In most legumes the auxin analog 2,4D (2,4-dichlorophenoxyacetic acid) induces high frequency of embryo production, but large numbers of these embryos are morphologically abnormal and unable to convert to plantlets (Garg et al., 1996). In pea and soybean, embryos with normal morphology are obtained using the auxin NAA (1-naphthaleneacetic acid; Lazerri et al., 1987; Ozcan et al., 1993). Induction of somatic embryogenesis by cytokinin alone is rare but it is required for induction of somatic embryos from intact seedlings of Phaseolus species (Malik and Saxena, 1992a). In contrast, its presence strongly inhibited direct somatic embryo induction in pea and soybean (Kysley and Jacobsen, 1990; Lazzeri et al., 1987). The highly embryogenic effect of cytokinin is observed for indirect somatic embryogenesis after an extensive callus induction step notably in the genera Medicago and Trifolium. The synthetic plant growth regulator thidiazuron (TDZ) with both auxin and cytokinin activity possess remarkable regeneration ability in some leguminous plants like bean (Malik and Saxena, 1992), peanut (Arachis hypogeal; Murthy et al., 1995) and some diploid Medicago species (lantcheva et al., 1999). Interestingly, in peanut TDZ induced somatic embryogenesis is genotype independent (Saxena et al., 1992). Somatic embryo maturation is a crucial step during somatic embryogenesis and it has been shown that cytokinin alone or in combination with an auxin is important for this somatic embryo maturation in chickpea (Cicer arietinium; Kumar et al., 1995) and Vigna aconitifolia (Kumar et al., 1988).

Regeneration/transformation procedures based on repetitive somatic embryogenesis (a process of formation of secondary somatic embryos on primary ones) have been described for several legume species including alfalfa, soybean, peanuts and diploid medics (Lupotto 1983; Finer and Nagasawa, 1988; Parott and Bailey, 1993; lantcheva et al., 1999). Repetitive embryogenesiswas explored for Agrobacterium-mediated transformation of $M$. sativa (Nincovic et al., 1995) and M. truncatula (lantcheva et al., 2005). In soybean, regeneration and transformation protocols are established either on somatic embryogenesis using immature embryos (Parott at al. 1989) or cotyledons (Hinchee et al., 1988) or organogenesis from cotyledonary nodes or geminating seeds (Olholt et al., 2003). In chickpea, different regeneration/transformation protocols have been developed using leaf or stem (Srinivasan and Sharma 1991; or cotyledons and cotyledonary nodes (Bhattacharjee et al., 2010) 
or mature embryogenic axes (Mehrotra et al., 2011). In pea, segments of embryogenic axis (Polowick et al., 2000), cotyledonary nodes (Bean et al., 1997), and immature cotyledons (Grant et al., 2003) have been used for transformation. The above protocols are generally genotype dependent, less efficient and lead to production of chimeric plants.

In addition to the peculiarity of the in vitroregeneration of legume, another bottle neck to generate transgenic legume plants is the choice of the Agrobacterium strain used for transformation. Some strains used currently for Brassicaceae or Solanaceae species (for example strain LBA4404) are less efficient in transforming legume cells. Legume transformation has been improved by the use of hyper virulent strains like EHA105, EHA101 (Hood et al., 1993), KYRT1 (Grant et al., 2003; Ko et al., 2003) and eventually by adapting protocols to reduce the biotic stress created by the infection. Use of acetosyringone (improved virulence gene activation) and/or stress protectants like cystein and dithiothreitol, offers improved Agrobacterium-mediated plant transformation in soybean (Olhoft et al., 2003, Paz et al., 2004), maize (Vega et al., 2008) and cell suspension of $M$. truncatula (lantcheva et al., unpublished data). Finally the optimization of selection-marker used during the transformation procedure is also important and should be carefully defined for each plant species (Cosson et al., 2006).

An alternative method for production of transgenic material uses the $A$. rhizogenes-mediated transformation, as the production of transgenic legume plants is not always necessary when studying symbiosis. This is a rapid method to produce hairy roots on composite plants (transformed roots are induced on a non-transformed plant). Induced transgenic hairy root system can be nodulated by symbiotic bacteria or can establish symbiosis with mycorrhizal fungi. Hairy roots possess hormone-independent growth, are much more branched, and contain numerous root hairs. The capacity to produce chimeric transgenic plants is an important tool for scientists involved in root, nitrogen fixing and endomycorrhizal symbiotic studies. A. rhizogenes-mediated transformation in legumes was first described for Lotus corniculatus (Jensen et al., 1986). Such transgenic roots can be nodulated directly and this technology has now been reproduced in other (model) legumes such as $M$. truncatula (Boisson-Dernier et al., 2001; Gourion et al., 2012), V. aconitifolia (Lee et al., 1993), L. japonicus (Stiller et al., 1997), red clover (Diaz et al., 2000), bean (Estrada-Navarrete et al., 2006), Aeschinomene indica (Bonaldi et al., 2010) and peanut (Sinharoy et al., 2009).

In the past 15 years, the efforts of the legume scientific community concentrated on studying host genes involved in the legume-rhizobium symbiosis. As indicated above, two model species, $M$. truncatula and $L$. japonicus are popularly used for these studies. Subsequently, a large number of genes involved in NF perception and symbiotic signal transduction, bacterial infection, nodule organogenesis, and regulation of nitrogen fixation have been identified in these two species. It should be noted that the arbuscular mycorrhizal (AM) symbiosis can also be studied in these model leguminous plants and has benefited from the knowledge developed for the rhizobia symbiosis. However, the benefit of the transformation methods to study AM symbiosis will not be discussed here. This review emphasizes the role of the transformation approach as a tool for understanding the functions of key regulatory and signaling related genes, as well as the role of phytohormones and other signal molecules involved in different stages of the symbiosis between legume plants and rhizobia.

\section{Insertion mutagenesis}

One important outcome of establishing regeneration/transformation protocols in model legumes was the possibility to develop insertion mutagenesis in these plants. Insertion mutagenesis has

TABLE 1

A REPRESENTATIVE (NON EXHAUSTIVE) LIST OF SYMBIOTIC GENES STUDIED USING AGROBACTERIUM-MEDIATED STABLE OR HAIRY ROOT TRANSFORMATION IN M. TRUNCATULA

\begin{tabular}{|c|c|c|c|}
\hline Experiment & Gene & Gene function & References \\
\hline \multicolumn{4}{|c|}{ Agrobacterium tumefaciens-stable transformation } \\
\hline Gene fusion (GUS) & Enod12-early nodulin gene & Early nodule development & Chabaud et al. (1996) \\
\hline Gene fusion (GUS) & DNF2-GUS & Bacteroid maintenance & Bourcy et al., (2013) \\
\hline Gene fusion (GUS) & NOOT-GUS & Nodule identity & Couzigou et al., (2013) \\
\hline Overexpression & P5CS-(D-pyrroline-5-carboxylate synthetase) & Enhanced nodule activity during the condition of osmotic stress & Verdoy et al. (2006) \\
\hline $\begin{array}{l}\text { Ectopic expression of dominant negative } \\
\text { form of the AT SINAT5DN }\end{array}$ & SINA (Seven in Absentia Proteins ) & Affects plant growth and nodulation & Den Herder et al. (2008) \\
\hline $\begin{array}{l}\text { Genomic DMI2 construct fused to a dual } \\
\text { affinity tag }\end{array}$ & DMI2 (does not make infection) & Biochemical characterization of symbiotic receptor kinase & Reily et al (2012) \\
\hline \multicolumn{4}{|c|}{ Agrobacterium rhizogenes-hairy root transformation } \\
\hline Complementation & MtLyk3 (HCL) & NF entry receptor & Smit et al. (2007) \\
\hline Gene fusion (GUS) & MtIRE & Unknown & Pislariu et al., (2007) \\
\hline RNAi & $M t L y k 3(\mathrm{HCL})$ & NF entry receptor & Limpens et al., (2003) \\
\hline RNAi & NFP (nod factor perception) & NPF Nod factor perception & Arrighi et al. (2006) \\
\hline RNAi & $D M I 1$ (does not make infection) & DMI1 (calcium spiking) & Ane et al 2004 \\
\hline Complementation & NSP1, NSP2 Nodulation Signaling Pathway & Efficient nodulation & $\begin{array}{l}\text { Kalo et al., (2005); } \\
\text { Smit et al., (2005) }\end{array}$ \\
\hline Complementation; RNAi & $\begin{array}{l}\text { EFD ethylene response factor required for nodule } \\
\text { differentiation }\end{array}$ & Nodule initiation and development & Vernie et al. (2008) \\
\hline RNAi & $\mathrm{CHS}$ chalcone synthase & Nodule initiation and regulation of auxin transport & Wasson et al (2006) \\
\hline RNAi & MtCRE1 Cytokinin Response1 & Control of nodulation & Gonzalez-Rizzo et al. (2006) \\
\hline RNAi & $L A X$ auxin influx carrier & Early steps of nodule development & Billy et al. (2001) \\
\hline \multirow[t]{2}{*}{ RNAi } & PIN auxin efflux carrier & Nodule development & Huo et al. (2006). \\
\hline & CDC16 gene / CELL DIVISION CYCLE16 / & Root and nodule development & Kuppusamy et al. et al. (2009) \\
\hline
\end{tabular}


been instrumental in the development of molecular tools necessary for the understanding of plant physiology and development because it allows efficient gene disruption (KO mutations) and gene tagging that facilitate isolation of the mutated gene. In both L. japonicus and M. truncatula, the T-DNA tagging strategy developed in Arabidopsis thaliana could not be applied because of the absence of high throughput transformation protocols (Brocard et al., 2006) necessary for the production of large insertion mutant collections. On the contrary, this was possible using the Tnt1 and MERE retroelements in M. truncatula (d'Erfurth et al., 2003; Tadege et al., 2008; Revalska et al., 2011; Rakocevic et al., 2009) and Lore1 retroelement in L. japonicus (Madsen et al., 2005; Fukai et al., 2012). The Tnt1 tobacco retroelement was introduced in $M$. truncatula using a T-DNA based approach but it was shown that its autonomous transposition is induced only during in vitro somatic embryogenesis. The MERE1 endogenous retroelement was first characterized as a somaclonal mutation in a transgenic line obtained after T-DNA transformation. Similarly to Tnt1, MERE1 transposes during the process of in vitro somatic embryogenesis. The Lore 1 element in $L$. japonicus was characterized as an element responsible for somaclonal variations in the progeny of plants, obtained through in vitro culture regeneration. Transposition occurs at high frequency in genes of these plants. The retroelement-mediated insertion mutant collections in these two plants have now allowed the characterization of numerous symbiotic mutants in both the plant species (http://medicago-mutant.noble.org/mutant/, http:// www.kazusa.or.jp/lotus, see also Table 1 and Table 2) and continue to contribute to the understanding of the symbiotic process in legume plants.

\section{Model plants}

\section{Medicago truncatula, a model for indeterminate nodule for- mation}

In $M$. truncatula, the model plant to study indeterminate nodules, the different transformation technologies have facilitated the identification of the signaling pathway necessary for symbiotic in- teractions. Both stable transformation and hairy root transformation systems have been used in $M$. truncatula. The hairy root system was used mainly for complementation or gene knockdown. In addition, promoter-GUS fusions or fusions to other reporter genes were used in these studies. Only few of the research investigations related to endosymbiosis were done using stable transgenic plants. This is because obtaining stable transformants through Agrobacterium-mediated transformation is labour-intensive, expensive and time consuming. There are two pioneer studies of Chabaud et al. (1996) and Trinh et al. (1998) on transformation of $M$. truncatula and $M$. sativa with transcriptional reporter constructs. These stable transgenic plants have the advantage that they can be reproduced, propagated and crossed to mutant genotypes and used for different studies.

Some examples of the results obtained, using transgenic technology, to understand the $M$. truncatula-Sinorhizobium symbiosis based on stable and hairy roots transformation methods are summarized below in Table 1. A transgenic nodule expressing the GUS reporter gene in vascular tissues is schown Fig. 1B.

\section{Lotus japonicas, a model for determinate nodule formation}

$L$. japonicus a member of the genera Loteae is used as a model legume to study determinate type of nodulation (Handberg and Stougaard, 1992). Similar to what has been achieved in M. truncatula, the different transformation technologies developed for $L$. japonicus have facilitated the identification of various components of the Nod factor signaling pathway necessary for the interaction. Some examples using the transgenic technology to understand the L. japonicus-Mesorhizobium lotisymbiosis are outlined in Table 2. A transgenic Lotus nodule expressing a cyclin-like $F$ box-GUS gene fusion is schown Fig. $1 \mathrm{C}$.

\section{Crop plants}

\section{Alfalafa (Medicago sativa)}

Alfalfa is one of the major forage crops in the world and also the first legume species regenerated and transformed in vitro (Deak

TABLE 2

A REPRESENTATIVE (NON EXHAUSTIVE) LIST OF SYMBIOTIC GENES STUDIED USING AGROBACTERIUM-MEDIATED STABLE OR HAIRY ROOT TRANSFORMATION IN L. JAPONICUS

\begin{tabular}{|c|c|c|c|}
\hline Experiment & Gene & Gene function & References \\
\hline \multicolumn{4}{|c|}{ Agrobacterium tumefaciens-stable transformation } \\
\hline pGH3:GUS:GFP & Soybean auxin responsive promoter. & Auxin distribution during the process of nodule development & Pacios-Bras et al. (2003) \\
\hline Complementation & HAR1 & Control of the nodule number & Nishimura et al., (2002a) \\
\hline Complementation & ASTRAY & Control of the nodule number & Nishimura et al., (2002b) \\
\hline Complementation & IGN1 & Bacteroid persistence & Kumagai et al., (2007) \\
\hline Overexpression & NahG salicylate hydroxylase & Reduction of SA levels in respect to control of nodule & Stacey et al. (2006) \\
\hline \multicolumn{4}{|c|}{ Agrobacterium rhizogenes-hairy root transformation } \\
\hline Complementation & NFR1; NFR5 nod factor recognition & Initiation of the symbiotic interaction & Radutoiu et al. (2003); Madsen et al., (2003) \\
\hline Complementation & CASTOR POLLUX & Ion channels essential for perinuclear calcium spiking & Miwa et al., (2006) \\
\hline Complementation & SEN1 & Nitrogen fixation & Hakoyama et al. (2011) \\
\hline Complementation & NUP133 symbiotic nucleoporin & Rhizobial colonization & Kanamori et al. (2006) \\
\hline Complementation & NUP85 symbiotic nucleoporin & Rhizobial colonization & Saito et al. (2007) \\
\hline Complementation & CCAMK CYCLOPS & Initiation of symbiotic interaction & Kistner et al, (2005) \\
\hline Complementation & NIN & Initiation of nodule organogenesis & Schauser et al, (1999) \\
\hline Gene function & Cytokinin receptor & NF signaling & Tirichine et al., (2006) \\
\hline Gene function & $\mathrm{Ca} 2+/$ Calmoduline dependant kinase & NF signaling & Tirichine et al., (2007) \\
\hline Complementation & $N S P 1 ; N S P 2$ & Formation of infection threads & Heckmann et al, (2006) \\
\hline
\end{tabular}


et al., 1986; Pichon et al., 1992). The cultivated alfalfa is perennial, tetraploid and allogamous and possesses a relatively large genome, making it not suitable for genetic analysis. In contrary, M. truncatula that is closely related to alfalfa has a relatively small sized diploid genome making it suitable for genetic/genomic studies (see above). However, some research related to the role of legume lectins during symbiosis was done in alfalfa. One of the proposed functions of legume lectins is to determine the specificity of the rhizobia-legume symbiosis (Hirsh 1999). For this study, Brill et al. (2004) obtained transgenic alfalfa plants that expressed the alfalfa lectin MsLEC1 and MsLEC2 in sense and antisense orientations. MsLEC1-antisense (LEC1AS) plants were stunted, exhibited hypernodulation phenotype, and developed not only abnormally large nodules but also numerous small nodules, both of which senesced prematurely. MsLEC2-antisense plants were intermediate in growth and nodule numbers compared with LEC1AS. To confirm lectin function, seed lectin gene ( $P S L$ ) from pea was expressed in white clover hairy roots. Transformed "hairy" roots were nodulated by the pea specific symbiont Rhizobium leguminosarum bv. viciae (Díaz et al., 2000) thus demonstrating the role of the lectins in the specificity of symbiotic interaction.

\section{Pea (Pisum sativum)}

Pea has been a model organism in genetic research for more than a century. Intensive genetic and phenotypic analyses using pea symbiotic mutant collections showed that more than 40 genes are involved in the symbiotic process (Tsyganov et al., 2002). However, pea is an orphan species among legumes in respect to root symbioses (nodulation and mycorrhiza-formation) molecular studies. Pea has a larger genome, relatively long life cycle and larger size thus making it unattractive to do genetic research when compared to other model legumes. In addition, the pea genome sequence is not yet publically available and there are no efficient regeneration/transformation-systems developed. For this reason only few laboratories have published symbiotic studies using transgenic pea plants (Krejci et al., 2007; DeMason et al., 2013). There is only one report related to symbiotic studies in pea where Agrobacterium-mediated transformation has been used to study ENOD12A:GUSgene construct (Schneider et al., 1999). In addition, there is one report showing successful formation of hairy roots on composite pea plant, for complementation of a nodulation mutant (Hohnjec et al., 2003). Clemow et al. (2011) recently established a protocol for the rapid development of transformed hairy roots on pea composite plants using $A$. rhizogenes. The authors showed that the transformed roots of two non-nodulating pea sym10 mutants complemented with the wild-type gene. This protocol should now facilitate the studies done with various pea symbiotic mutants.

\section{Soybean (Glycine max)}

Soybean is one of the most important legume crops in the world. Genetically modified (transgenic) soybean plants have been produced mainly to improve their field performance and to understand gene function. For this, Agrobacterium-mediated or biolistic (particle bombardment) methods have been used to transform shoot meristems, cotyledonary nodes or cultured embryogenic tissues (Finner et al., 1991; Hinchee et al., 1988). These transformation techniques are labor-intensive and inefficient for large scale production. For studies related to root biology and symbiotic and pathogenic interactions, an efficient $A$. rhizogenes transformation method was developed by Kereszt et al. (2007). Indrasumunar et al. (2011) described two highly related lipo-oligochitin LysM-type receptor kinase gene products (GmNFR1 $\alpha$ and GmNFR1 $\beta$ ) as putative Nod factor receptor components in soybean. Transgenic hairy roots of non-nodulating mutant lines overexpressing GmNFR1a but not GmNFR1b form nodules with Bradyrhizobium japonicum, demonstrating the functionality of GmNFR1a. Other host genes referred as $R j$ genes have been identified as controlling nodulation traits upon inoculation with compatible Bradyrhizobium (Hayashi et al., 2012). In addition Radwan et al. (2012) have usedRNA interference (RNAi) approach to silence SGF14C and SGF14I gene expression in soybean roots using $A$. rhizogenes-mediated root transformation. Silencing of these genes encoding 14-3-3 proteins resulted in reduced numbers of mature nodules and large numbers of arrested nodule primordia following $B$. japonicum inoculation. This work suggests a critical role of 14-3-3 proteins in early stages of nodule development. Recently it was shown that soybean ureide transporters play a critical role in nodule development, nodule functioning and in nitrogen export out the symbiotic organ. For this, Collier and Tegeder (2012) demonstrated, using A. rhizogenes transformation combined with an RNAi approach, the function of two soybean proteins, GmUPS1-1 and GmUPS1-2 in allantoin and allantoic acid transport out of the nodule. The repression of GmUPS1-1 and GmUPS1-2 in nodules resulted in an accumulation of ureides and decreased nitrogen partitioning between roots and shoots.

\section{Common bean (Phaseolus vulgaris) and cowpea (Vigna un- guiculata)}

Consortia focusing on common bean (www.phaseolus.net) and cowpea (http://www.entm.purdue.edu/ngica/) have allowed making progresses in these two plants. For common bean and cowpea, genetic transformation protocols are not well established. Although progress has been made in establishing a transformation protocol for Phaseolus acutifolius (Zambre et al., 2005), the developed protocol is not routinely used. By using $A$. rhizogenes-mediated hairy root transformation, Estrada-Navarrete et al.,2006) reported the successful production of composite plants for the otherwise transformation recalcitrant bean species, $P$. vulgaris, $P$. coccineus, $P$. lunatus and $P$. acutifolius.

\section{Conclusions}

Leguminous plants are recognized worldwide because of their environmental and agricultural benefits. Recent progresses in molecular biology, genomics, transcriptomics, proteomics, metabolomics and bioinformatics of model legumes, $M$. truncatula and $L$. japonicus have provided new opportunities for deciphering gene function in legumes. The genome sequences or draft genomes of $M$. truncatula, L. japonicus, G. max, $P$. vulgaris and $C$. arietum are now available (www.phytozome.net; http://cicar.comparativelegumes.org). These legume plants share considerable genetic synteny with other crop legumes and this has allowed the successful translation of knowledge from these well characterized legumes to other agriculturally important legumes that are not well characterized. A long-lasting research idea is to transfer the legume genes required to establish symbiosis with nitrogen-fixing rhizobia to non-legume crop species (Charpentier and Oldroyd, 2010). Such genetic modifications will require transfer of multiple 
genes or pathways. Recently, Untergasser et al.,2012) developed a vector able to transfer eight genes in one-step by Agrobacteriummediated transformation. Genes essential for $M$. truncatula to establish a symbiosis with rhizobia were transferred to four nonleguminous species; strawberry, poplar, tomato and tobacco and all the transgenes were shown to be expressed in the root tissue of these non-legumes. Long term efforts of scientists will then continue to focus on the establishment of successful symbiotic interactions of rhizobia with non-legume crops.

\section{References}

ANE JM, KISS GB, RIELY BK, PENMETSA RV, OLDROYD GE, AYAX C, LERVY J, DEBELLER F, BAEK J-M, KALO P, ROSENVERG C, ROE BA, LONG SR, DENARIE J, COOK DR (2004). Medicago truncatula DMI1 required for bacterial and fungal symbioses in legumes. Science 303: 1364-1367.

ARAÚJO SS, DUQUE ASRLA, SANTOS DMMF, FEVEREIRO MPS (2004). An efficient transformation method to regenerate a high number of transgenic plants using a new embryogenic line of Medicago truncatula cv. Jemalong. Plant Cell Tissue Organ Cult 78: 123-131.

ARCIONI S, DAMIANI F, PUPILLI F, PEZZOTTI M (1989). Somatic embryogenesis and somaclonal variation in Medicago sativa L. J Genet Breed 43: 223-230.

ARRIGHI JF, BARRE A, AMOR B, BERSOULT A, SORIANO LC, MIRABELLA R, CARVALHO-NIEBEL F, JOURNET E-P, GHERARDI M, HUGUET T, GEURTS R, DENARIE J, ROUGE P, GOUGH C (2006). The Medicago truncatula lysine motif-receptor like kinase gene family includes NFP and new nodule-expressed genes. Plant Physiol 142: 265-279

ATANASSOV A, BROWN DCW (1984). Plant regeneration from suspension culture and mesophyll protoplasts of Medicago sativa L. Plant Cell Tissue Organ Cult 3: 149-162.

BARBULOVAA, IANTCHEVAA, ZHIPONOVAM, VLAHOVAM, ATANASSOVA(2002). Establishment of embryogenic potential of economically important Bulgarian alfalfa cultivars (Medicago sativa L.). Biotechnol Biotechnol Eq 16: 55-63.

BEAN SJ, GOODING PS, MULLINEAUX PM, DAVIES DR (1997). A sample system for pea transformation. Plant Cell Rep 16: 513-519.

BHATTACHARJEE B, MOHAN M, NAIR S (2010). Transformation of chickpea: effect of genotype, explant, Agrobacterium-strain and composition of culture medium. Biol Plant 54: 21-32.

BILLYF de, GROSJEANC, MAYS, BENNETT M, GULLIMOREJV (2001). Expression studies on AUX1-like genes in Medicago truncatula suggest that auxin is required at two steps in early nodule development. Mol Plant-Microbe Interact 14:267-277.

BOISSON-DERNIER A, CHABAUD M, GARCIA F, BECARD G, ROSENBERG C, BARKER DG (2001). Agrobacterium rhizogenes-transformed roots of Medicago truncatula for the study of nitrogen-fixing and endomycorrhizal symbiotic associations. Mol Plant Microbe Interact 14: 695-700.

BONALDI K, GHERBI H, FRANCHE C, BASTIEN G, FARDOUX J, BARKER D, GIRAUD E, CARTIEAUX F (2010). The Nod factor-independent symbiotic signaling pathway: development of Agrobacterium rhizogenes-mediated transformation for the legume Aeschynomene indica. Mol Plant-Microbe Interact 23: 1537-1544.

BRILL LM, FUJISHIGE NA, HACKWORTH CA, HIRSH AM (2004). Expression of MsLEC1 Transgenes in Alfalfa Plants Causes Symbiotic Abnormalities. Mol Plant-Microbe Interact 17: 16-26.

BROCARD L, SCHULTZE M, KONDOROSI A, RATET P (2006). T-DNA mutagenesis in themodel plant Medicago truncatula: is it efficient enough for legume molecular genetics? CAB Reviews: Persp. Agricul. Vet. Sci. Nutrit. Nat. Res 1-7.

BOURCY M, BROCARD L, PISLARIU CI, COSSON V, MERGAERT P, TADEGE M, MYSORE KS, UDVARDI MK, GOURIONB, RATETP (2013). Medicago truncatula DNF2 is a PI-PLC-XD-containing protein required for bacteroid persistence and prevention of nodule early senescence and defense-like reactions. New Phytologist 197: 1250-1261.

CHABAUD M, LARSONNEAU C, MARMOGETC, HUGUETT (1996). Transformation of barrel medic (Medicago truncatula Gaertn.) by Agrobacterium tumefaciens and regeneration via somatic embryogenesis of transgenic plants with the MtENOD12 nodulin promoter fused to the gus reporter gene. Plant Cell Rep 15: 305-310.

CHARPENTIER M, OLDROYD G (2010) How close are we to nitrogen-fixing cereals?
Curr Opin Plant Biol 13: 556-564.

CLEMOW SR, CLAIRMONT L, MADSEN LH, GUINEL FC, (2011). Reproducible hairy root transformation and spot-inoculation methods to study root symbioses of pea. Plant Methods 7: 46.

COLLIER R, TEGEDER M (2012). Soybean ureide transporters play a critical role in nodule development, function and nitrogen export. Plant J 72: 355-367.

COSSON V, DURAND P, D'ERFURTHI, KONDOROSIA, RATETP (2006). Medicago truncatula transformation using leaf explants In: Methods Mol Biol, K Wang, ed, Agrobacterium Protocols, Vol 343. Human Press, Totowa, NJ, pp.115-127.

COUZIGOU JM, ZHUKOV V, MONDY S, ABU EL HEBA G, COSSON C, ELLIS THN, AMBROSE M, WEN J, TADEGE M, TIKHONOVICH I, MYSORE SK, PUTTERILL J, HOFER J, BORISOV AY, RATET P (2012). NODULE ROOT and COCHLEATA maintain nodule development and are legume orthologs of Arabidopsis BLADEON-PETIOLE genes. Plant Cell 24: 4498-4510.

CRANE S, WRIGHT E, DIXON RA, WANG Z-Y (2006). Transgenic Medicago truncatula plants obtained from Agrobacterium tumefaciens transformed roots and Agrobacterium rhizogenes transformed hairy roots. Planta 223: 1344-1354.

DEAK M, KISS GB, KONCZ C, DUDITS D (1986). Transformation of Medicago by Agrobacterium mediated gene transfer. Plant Cell Rep 5: 97-100.

DEMASON DA, CHETTY V, BARKAWI LS, LIU X, COHEN JD (2013). Unifoliata-Afila interactions in pea leaf morphogenesis. Amer J Bot 100: 478-496.

DENCHEV P, VELCHEVAM, ATANASSOVA (1991). Anew approach to direct somatic embryogenesis in Medicago. Plant Cell Rep 10: 338-341.

D'ERFURTH I, COSSON V, ESCHSTRUTH A, LUCAS H, KONDOROSI A, RATET $P$ (2003). Efficient transposition of the Tnt1 tobacco retrotransposon in the model legume Medicago truncatula. Plant J 34: 95-106.

DIAZ CL, SPAINK HP, KIJNE JW (2000). Heterologous rhizobial lipochitin oligosaccharides and chitin oligomers induce cortical cell divisions in red clover roots, transformed with the pea lectin gene. Mol Plant-Microbe Interact 13: 268-276.

ESTRADA-NAVARRETE G, ALVARADO-AFFANTRANGER X, OLIVARES J-E, DIAZ-CAMINO C, SANTANA O, MURILLO E, GUILLEN GJ, QUINTO C, LI D, GRESSHOFF PM, SANCHEZF (2006). Agrobacterium rhizogenes-transformation of the Phaseolus spp.: A tool for functional genomics. Mol Plant-Microbe Interact 19: 1385-1393.

FERGUSON BJ, INDRASUMUNAR A, HAYASHI S, LIN MH, LIN YH, REID DE, GRESSHOFF PM (2010). Molecular analysis of legume nodule development and autoregulation. J Integr Plant Biol 52: 61-76.

FINER JJ, NAGASAWA A (1988). Development of an embryogenic suspension culture of soybean (Glycine max Merill). Plant Cell Tissue Organ Cult 34: 125-132.

FINNER JJ, McMULLEN MD (1991). Transformation of soybean via particle bombardment of embryogenic suspension culture tissue. In vitro Cell Dev Biol27: 175-182.

FUKAI E, DOBROWOLSKA AD, MADSEN LH, MADSEN EB, UMEHARA $Y$ et al. (2008) Transposition of a 600 thousand-year-old LTR retrotransposon in the model legume Lotus japonicus. Plant Mol Biol 68: 653-663.

FUKAI E, SOYANO T, UMEHARA Y, NAKAYAMAS, HIRAKAWA H, TABATA S, SATO S, HAYASHIM (2012). Establishment of a Lotus japonicusgene tagging population using the exon-targeting endogenous retrotransposon LORE1. PlantJ69:720-730.

GARG L, BHANDARI NN, RANI V, BHOJWANI SS (1996). Somatic embryogenesis and regeneration of triploid plants in endosperm culture of Acacia nilotica. Plant Cell Rep. 15: 855-858.

GRAHAM PH, VANCE CP (2003). Legumes: Importance and constraints to greater use. Plant Physiol 131: 872-877.

GRANT JE, THOMSON LMJ, PITER-JOYCE MD, DALE TM, COOPER PA (2003). Influence of Agrobacterium tumefaciens strain on the production of transgenic pea (Pisum sativum L.) using immature cotyledons. Plant Cell Rep 15: 254-258.

GONZALEZ-RIZZO S, CRESPI M, FRUGIER F (2006). The Medicago truncatula CRE1 cytokinin receptor regulates lateral root development and early symbiotic interaction with Sinorhizobium meliloti. Plant Cell 18: 2680-2693.

GOURION B, BOURCY M, COSSON V, RATET P (2013) Protocols for growing plant symbioses; rhizobia. In Methods Mol. Biol., 953: 61-75.

HAKOYAMA T, NIIMI K, YAMAMOTO T, ISOBE S, SATO S, NAKAMURA Y, TABATA S, KUMAGAI H, UMEHARA Y, BROSSULEIT K, PETERSEN TR, SANDAL N, STOUGAARD J, UDVARDI MK, TAMAOKI M, KAWAGUCHI M, KOUCHI H, SUGANUMAN (2012). The integral membrane protein SEN1 is required for symbiotic nitrogen fixation in Lotus japonicus nodules. Plant Cell Physiol 53: 225-36. 
HANDBERG K, STOUGAARD J (1992). Lotus japonicus, an autogamous, diploid legume species for classical and molecular genetics. Plant J 2: 487-96.

HAYASHI M, SAEKI Y, HAGA M, HARADA K, KOUCHI H, UMERADA Y (2012). Rj (rj) genes involved in nitrogen-fixing root nodule formation in soybean. Breeding Science 61: 544-553.

HECKMANN AB, LOMBARDO F, MIWA H, PERRY JA, BUNNEWELL S, PARNISKE $M$, et al., (2006). Lotus japonicus nodulation requires two GRAS domain regulators, one of which is functionally conserved in a non-legume. Plant Physiol. 142: 1739-1750.

Den HERDER G, KEYSER A, RYCKE R, ROMBAUTS S, VAN DE VELDE W, CLEMENTE MR, VERPLANKE C, MERGAERT P, KONDOROSI E, HOLSTERD M, GOORMACHTIG S (2008). Seven in absentia proteins affect plant growth and nodulation in Medicago truncatula. Plant Physiol 148: 369-382.

HINCHEE MAW, CONNOR-WARD DV, NEWELL CA, MCDONNELL RE, SATO SJ, GASSER CS, FISCHHOFF DA, RE DB, FRALEY RT, HORSH RB (1988). Production of transgenic soybean plants using Agrobacterium-mediated DNA transfer. Bio/Technology 6: 915-922.

HINCHEE MAW, CONNOR-WARD DV, NEWELL CA, McDONELL RE, SATO SJ, HIRSH AM (1999). Role of lectins (and rhizobial exopolysaccharides) in legume nodulation. Curr Opin Plant Biol 2: 320-326.

HIRSH AM (1999). Role of lectins (and rhizobial exopolysaccharides) in legume nodulation. Curr Opin Plant Biol 2: 320-326.

HOFFMANN B, TRINH TH, LEUNG J, KONDOROSI A, AND KONDOROSI E (1997). A new Medicago truncatula line with superior in vitro regeneration, transformation and symbiotic properties isolated through cell culture selection. Mol Plant-Microbe Interact 10: 307-315

HOHNJEC N, PERLICKAM, PUHLERA, KUSTERH (2003). The Medicago truncatula sucrose synthase gene MtSucS1 is activated both in the infected region of root nodules and in the cortex of roots colonized by arbuscular mycorrhizal fungi. $\mathrm{Mol}$ Plant-Microbe Interact 16: 903-915.

HOOD EE, GELVIN SB, MELCHERS LS, HOEKEMA A (1993). New Agrobacterium helper plasmids for gene transfer to plants. Transgenic Res. 2: 208-218.

HUO X, SCHNABEL E, HUGHES K, FRUGOLI J (2006). RNAi Phenotypes and the localization of a Protein::GUS fusion imply a role for Medicago truncatula PIN genes in nodulation. J Plant Growth Regul 25: 156-165.

IANTCHEVA A, BAKALOVA E, VLAHOVA M, KONDOROSI E, ELLIOTT M AND ATANASSOV A (1999). Regeneration of diploid annual medics via direct somatic embryogenesis promoted by thidiazuron and benzylaminopurine. Plant Cell Rep 18: $904-910$.

IANTCHEVA A, VLAHOVA M, TRINH TH, BROWN S, SLATER A, ELLIOTT MC, ATANASSOVA(2001). Assessment of polysomaty, embryogenic potential, embryo formation and regeneration in liquid media for different species of diploid annual Medicago. Plant Sci 160: 621-627.

IANTCHEVA A, VLAHOVA M, ATANASSOV A (2005). Genetic transformation of Medicago truncatula using system for direct somatic embryogenesis promoted by TDZ. Biotechnol Biotechnol Eq 7: 50-56.

IANTCHEVA A, VLAHOVA M, ATANASSOV A (2008). Somatic embryogenesis from leaf explants of Medicago truncatula cv. Jemalong genotype 2HA http://www. noble.org/MedicagoHandbook/

INDRASUMUNARA, SEARLE I, LIN M-H, KERESZT A, MENA, CAROLLBJ GRESSHOFF PM (2011). Nodulation factor receptor kinase 1á controls nodule organ number in soybean (Glycine max L. Merr). Plant J 65: 39-50.

JENCEN JS, MARCKER KA, OTTEN L, SHELL J (1986). Nodulespecific expression of a chimeric soybean leghemoglobin gene in transgenic Lotus corniculatus. Nature 321: 669-674.

KALÓ P, GLEASON C, EDWARDS A, MARSH J, MITRA RM, HIRSCH S, JAKAB J, SIMS S, LONG SR, ROGERS J, KISS GB, DOWNIE JA, OLDROYD GE (2005). Nodulation signaling in legumes requires NSP2, a member of the GRAS family of transcriptional regulators. Science 308: 1786-1789.

KANAMORI N, MADSEN LH, RADUTOIU S, FRANTESCU M, QUISTGAARD EM, MIWAH, DOWNIE JA, JAMES EK, FELLE HH, HAANING LL, JENSEN TH, SATO S, NAKAMURA Y, TABATA S, SANDAL N, STOUGAARD J (2006) A nucleoporin is required for induction of $\mathrm{Ca} 2+$ spiking in legume nodule development and essential for rhizobial and fungal symbiosis. Proc. NatlAcad. Sci. USA 103: 359-364.

KERESZT A, LI D, INDRASUMUNAR A, NGUYEN CDT, NONTACHAIYAPOOM S, KINKEMA M, GRESSHOFF PM (2007). Agrobacterium rhizogenes-mediated transformation of soybean to study root biology. Nature protocols 2: 948-952.

KISTNER C, WINZER T, PITZSCHKE A, MULDER L, SATO S, KANEKO T, et al., (2005). Seven Lotus japonicus genes required for transcriptional reprogramming of the root during fungal and bacterial symbiosis. Plant Cell 17: 2217-2229.

KO T-S, LEE S, KRASNYANSKI S, KORBAN SS (2003). Two critical factors are required for efficient transformation of multiple soybean cultivars: Agrobacterium strain and orientation of immature cotyledonary explant/.Theor. Appl. Genetics 107: 439-447.

KREJČí P, MATUŠKOVÁ P, HANÁČEK P, REINÖHL V, PROCHÁZKA S (2007). The transformation of pea (Pisum sativum L.): applicable methods of Agrobacterium tumefaciens-mediated gene transfer. Acta Physiologiae Plantarum 29: 157-163.

KUMAGAI H, HAKOYAMA T, UMEHARA Y, SATO S, KANEKO T, TABATA S, KOU$\mathrm{CHI} \mathrm{H}$ (2007). A novel ankyrin-repeat membrane protein, IGN1, is required for persistence of nitrogen-fixing symbiosis in root nodules of Lotus japonicus. Plant Physiol 143: 1293-305

KUMAR AS, GAMBORG OL, NABORS MW (1988). Plant regeneration from cell suspension cultures of Vigna aconitifolia. Plant Cell Rep 7: 138-144.

KUMAR VD, KIRTI PB, SACHAN JKS, CHOPRA VL (1995). Picloram induced somatic embryogenesis in chickpea (Cicer arietinum L.). Plant Sci 109: 207-213.

KUPPUSAMYKT, IVASHUTAS, BUCCIARELLIB, VANCE CP, GANTT JS, VANDERBOSCH KA (2009). Knockdown of CELL DIVISION CYCLE16 reveals an inverse relationship between lateral root and nodule numbers and a link to auxin in Medicago truncatula. Plant Physiol 151: 1155-1166.

KYSLEY W, JACOBSEN H (1990). Somatic embryogenesis from pea embryos and shoots apices. Plant Cell Tissue Organ Cult 20: 7-14.

LAZZERI PA, HILDENBRAND DF, COLLINS GB (1987). Soybean somatic embryogenesis:effects of hormones and culture manipulations. Plant Mol Biol Rep 10: 209-220.

LEE NG, STEINB, SUZUKIH, VERMADPS (1993). Expression of antisense nodulin-35 RNAin Vigna aconitifoliatransgenic root nodules retards peroxisome development and affects nitrogen availability to the plant. Plant $J$ 3: 599-606.

LIMPENS E, FRANKEN C, SMIT P, WILLEMSE J, BISSELING T, GEURTS R (2003). LysM domain receptor kinases regulating rhizobial Nod factor-induced infection. Science 302: 630-633.

LUPOTTO E (1983). Propagation of an embryogenic culture of Medicago sativa L. Pflanzenphysiol 111: 95-104

MACLEAN NL, NOWAKJ (1988). Inheritance of somatic embryogenesis in red clover (Trifolium pretense L.). Theor Appl Genet 97: 557-562.

MADSEN EB, MADSEN LH, RADUTOIU S, OLBRYT M, RAKWALSKA M, SZCZYGLOWSKI K, SATO S, KANEKO T, TABATA S, SANDAL N, STOUGAARD J (2003). A receptor kinase gene of the LysM type is involved in legume perception of rhizobial signals. Nature 425: 637-640

MADSEN LH, FUKAI E, RADUTOIU S, YOST CK, SANDAL N et al. (2005). LORE1, an active low-copy-number Gypsy retrotransposon family in the model legume Lotus japonicus. Plant J 44: 372-381

MALIK K, SAXENA P (1992). Regeneration in Phaseolus vulgaris L.: High frequency induction of direct shoot formation in intact seedlings by BAP and TDZ. Planta 186: 384-388.

MALIK KA, SAXENA PK (1992a). Somatic embryogenesis and shoot regeneration from intact seedlings of Phaseolus acutifolius, $P$. aureus (L.) Wilczek, P. coccineus L. and P. wrightii L. Plant Cell Rep 11: 163-168.

MEHROTRAM, SANYAL I, AMLADV (2011). High efficiency Agrobacterium mediated transfromation of chickpea (Cicer arietinumL.) and regeneration of insect-resistant transgenic plants. Plant Cell Rep 30: 1603-1616.

MIWA H, SUN J, OLDROYD GE, DOWNIE JA (2006). Analysis of Nod-factor-induced calcium signaling in root hairs of symbiotically defective mutants of $L$ otus japonicus. Mol Plant-Microbe Interact 19: 914-923.

MURTHY BNS, MURSH SJ, SAXENA PK (1995). Thidiazuron induced somatic embryogenesis in intact seedlings of peanut (Arachis hypogaea); Endogenous growth regulator levels and significance of cotyledons. Physiol Plant 94: 268-276.

NINKOVIC S, MILJUS-DJUKIC J, MIRJANAN (1995). Genetic transformation of alfalfa somatic embryos and their propagation through repetitive somatic embryogenesis. Plant Cell Tissue Organ Cult 42: 255-260.

NISHIMURAR, HAYASHI M, WU GJ, KOUCHIH, IMAIZUMI-ANRAKUH, MURAKAM Y, KAWASAKIS, AKAOS, OHMORI M, NAGASAWAM, HARADAK, KAWAGUCH 
M (2002a). HAR1 mediates systemic regulation of symbiotic organ development. Nature 420: 426-429.

NISHIMURAR, OHMORI M, FUJITAH, KAWAGUCHIM(2002b). A Lotus basic leucine zipper protein with a RING-finger motif negatively regulates the developmental program of nodulation. Proc Natl Acad Sci USA 99: 15206-15210.

NOLAN KE, ROSE RJ, GORST JG (1989). Regeneration of Medicago truncatula from tissue culture: increased somatic embryogenesis using explant from regenerated plants. Plant Cell Rep 8: 278-281.

OLDROYD GE, MURRAY JD, POOLE PS, DOWNIE JA (2011). The rules of engagement in the legume-rhizobial symbiosis. Annu Rev Genet 45: 119-144.

OLHOFT PM, FLAGEL LE, DONOVAN CM, SOMERS DA (2003). Efficient soybean transformation using hygromicin B selection in the cotyledonary-node method. Planta 216: 723-735.

OZCAN S, BARGHCHI M, FIREK S, DRAPER J (1993). Efficient adventitious shoot regeneration and somatic embryogenesis in pea. Plant Cell Tissue Organ Cult 34: 271-277.

PARROTT WA, HOFFMAN LM, HILDEBRAND DF, WILLIAMS EG, COLLINS GB (1989). Recovery of primary transfromants of soybean. Plant Cell Rep 7:615-617.

PARROTT WA, BAILEY MA (1993). Characterization of recurrent somatic embryogenesis of alfalfa on auxin-free medium. Plant Cell Tissue Organ Cult 32: 69-76.

PACIOS-BRAS C, SCHAMAN HRM, BOOT K, ADMIRAAL P, LANGERK JM, STOUGAARD J, SPAINK HP (2003). Auxin distribution in Lotus japonicus during root nodule development. Plant Mol Biol 52: 1169-1180.

PAZ MM, SHOU H, GUO Z, ZHANG Z, BANERJEEAK, WANG K (2004). Assessment of conditions affecting Agrobacterium-mediated soybean transformation using cotyledonary node explant. Euphytica 136: 167-179.

PICHON M, JOURNETEP, DEDIEUA, BILLY F de, TRUCHET G, BARKERDG (1992). Rhizobium meliloti elicits transient expression of the early nodulin gene Enod12 in the differentiating root epidermis of transgenic alfalfa. Plant Cell 4: 1199-1211.

PISLARIU CI, DICKSTEIN R (2007). An IRE-like AGC kinase gene, MtIRE, has unique expression in the invasion zone of developing root nodules in Medicago truncatula. Plant Physiol 144: 682-94

POLOWIK PL, QUANDT J, MAHON JD (2000). High ability of pea transformation technology to transfer genes into peas adapted to western Canadian growing conditions. Plant Sci 153: 161-170.

RADUTOIU S, MADSEN LH, MADSEN EB, FELLE HH, UMEHARA Y, GRONLUND $M$, et al.,2003). Plant recognition of symbiotic bacteria requires two LysM receptorlike kinases. Nature 425: 585-592.

RADWAN O, WU X, GOVINDARAJULU M, LIBAULT M, NEECE DJ, OH M-H, BERG RH, STACEY G, TAYLOR CG, HUBER SC, CLOUGH SJ (2012). 414-3-3 proteins SGF14c and SGF14I play critical roles during soybean nodulation. Plant Physiol 160: 2125-2136.

RAKOCEVIC A, MONDY S, TIRICHINE L, COSSON V, BROCARD L, IANTCHEVA A, CAYREL A, DEVIER B, ABU EL-HEBA GA, RATET P (2009). MERE1, a LowCopy-Number Copia-Type Retroelementin Medicago truncatula Active during Tissue Culture. Plant Physiol 151: 1250-1263.

REISCHB, BINGHAMET (1981). Selection and characterization of ethionine resistant alfalfa (Medicago sativa L.) cell lines. Theor Appl Genet 59: 89-94.

REVALSKA M, VASSILEVA V, GOORMACHTIG S, HAUTEGEM T, RATET P, IANTCHEVA A (2011). Recent Progress in Development of Tnt1 Functional Genomics Platform for Medicago truncatula and Lotus japonicus in Bulgaria. Current Genomics 12: 147-152.

RIELYBK, LARRAINZARE, HANEY CH, MUNJ-H, QUINTANAEG, GONZALEZEM, YUH-J, TRICOLID, EHRHARDT DW, LONG SR, COOK DR (2013) Development of tools for the biochemical characterization of the symbiotic receptor-like kinase DMI2. Mol Plant-Microbe Interact 26: 216-226.

SAITO K, YOSHIKAWA M, YANO K, MIWA H, UCHIDA H, ASAMIZU E, SATO S, TABATAS, ANRAKU HI, UMEHARAY, KOUCHI H, MUROOKAY, SZCZYGLOWSKI K, DOWNIE JA, PARNISKE M, HAYASHI M, KAWAGUCHI M (2007). NUCLEOPORIN85 is required for calcium spiking, fungaland bacterial symbioses, and seed production in Lotus japonicus. Plant Cell 19: 610-624.

SAMAC DA, TESFAYE M, DORNBUSCH M, PUREV S, TEMPLE SJ (2004). A comparison of constitutive promoters for expression of transgenic alfalfa (Medicago sativa). Transgenic Res 13: 349-361.

SAXENAPK, MALIK KA, GILL R (1992). Induction by thidiazuron of somatic embryogenesis in intact seedlings of peanut. Planta 187: 421-424.
SCHAUSER L, ROUSSIS A, STILLER J. STOUGAARD J (1999). A plant regulator controlling development of symbiotic root nodules. Nature 402: 191-195.

SCHNEIDER A, WALKER SA, POYSER S, SAGAN M, ELLIS THN, DOWNIE JA (1999). Genetic mapping and functional analysis of a nodulation-defective mutant (sym19) of pea (Pisum sativum L.). Mol Gen Genet 262: 1-11.

SINHAROY S, SAHA S, CHAUDHURY SR, DASGUPTA M (2009). Transformed hairy roots of Arachis hypogea: a tool for studying root nodule symbiosis in a non-infection thread legume of the Aeschynomeneae tribe. Mol Plant-Microbe Interact 22: 132-142.

SMITP, RAEDTS J, PORTYANKO V, DEBELLÉ F, GOUGHC, BISSELINGT, GEURTS $R$ (2005). NSP1 of the GRAS protein family is essential for rhizobial Nod factorinduced transcription. Science 308: 1789-1791.

SMIT P, LIMPENS E, GEURTS R, FEDOROVA E, DOLGIKH E, GOUGH C, BISSELING T (2007). Medicago LYK3, an Entry Receptor in Rhizobial Nodulation Factor Signaling. Plant Physiol 145: 183-191.

SRINIVASAN MT, SHARMA RP (1991). Agrobacterium mediated genetic transformation of chickpea (Cicer arietinum). Indian J Exp Biol 29: 758-761.

SRINIVASAN C, LIUZ, HEIDMANN I, SUPENAE, FUKUOKAH, JOOSEN R, LAMBALK J, ANGENENT G, SCORZA R, CUSTERS J, BOUTILIER K (2007). Heterologous expression of the BABY BOOM AP2/ERF transcription factor enhances the regeneration capacity of tobacco (Nicotiana tabacum L.). Planta 225: 341-351.

STACEY G, McALVIN CB, KIM S-Y, OLIVARES J, SOTO MJ (2006). Effects of endogenous salicylic acid on nodulation in the model legumes Lotus japonicus and Medicago truncatula. Plant Physiol 141: 1473-1481.

STILLER J, MARTIRANI L, TUPPALE S, CHIAN RJ, CHIURAZZI M, GRESSHOFF PM (1997). High frequency transformation and regeneration of transgenic plants in the model legume Lotus japonicus. J Exp Bot 48: 1357-1365.

TADEGE M, WEN J, HE J, TU H, KWAK Y, ESCHSTRUTHA, CAYRELA, ENDRE G, ZHAO PX, CHABAUD M, RATET P, MYSORE KS (2008). Large-scale insertional mutagenesis using the Tnt1 retrotransposon in the model legume Medicago truncatula. Plant J 54: 335-347.

TIRICHINE L, SANDAL N, MADSEN LH, RADUTOIU S, ALBREKTSEN AS, SATO S, ASAMIZU E, TABATA S, STOUGAARD J (2007). A gain-of-function mutation in a cytokinin receptor triggers spontaneous root nodule organogenesis. Science 315: 104-107.

TIRICHINE L, IMAIZUMI-ANRAKUH, YOSHIDAS, MURAKAMIY, MADSENLH, MIWA H, NAKAGAWA T, SANDAL N, ALBREKTSEN AS, KAWAGUCHI M, DOWNIE A, SATO S, TABATA S, KOUCHI H, PARNISKE M, KAWASAKI S, STOUGAARD J (2006). Deregulation of a Ca2+/calmodulin-dependent kinase leads to spontaneous nodule development. Nature 441: 1153-1156.

TRINTH TH, RATET P, KONDOROSI E, DURAND P, KAMATE K, BAUER P, KONDOROSI A (1998). Rapid and efficient transformation of diploid Medicago truncatula and Medicago sativa spp. falcata lines improved in somatic embryogenesis. Plant Cell Rep 17: 345-355.

TSYGANOV VE, VOROSHILOVA VA, PRIEFER UB, BORISOV AY, TIKHONOVICH IA (2002). Genetic dissection of initiation of the infection process of nodule tissue development in the Rhizobium-pea (Pisum sativum L.) symbiosis. Ann Bot 89: 357-366

UNTERGASSER A, BIJL GJM, LIU W, BISSELING T, SCHAART JG, GEURTS R (2012). One-Step Agrobacterium Mediated Transformation of Eight Genes Essential for Rhizobium Symbiotic Signaling Using the Novel Binary Vector System Phuge. PLOS ONE 7: e47885.

VEGA JM, YU W, KENNON AR, CHEN X, ZHANG ZJ (2008). Improvement of Agrobacterium-mediated transformation in $\mathrm{Hi}$-II maize (Zea mays) using standard binary vectors. Plant Cell Rep 27: 297-305.

VERDOY D, DE LAPEÑA TC, REDONDO FJ, LUCAS MM, PUEYO JJ (2006). Transgenic Medicago truncatula plants that accumulate proline display nitrogen-fixing activity with enhanced tolerance to osmotic stress Plant Cell and Environment 29: 1913-1923.

VERNIE T, MOREAU S, DE BILLY F, PLET J, COMBIER JP, ROGER C, OLDROYD G, FRUGIER F, NIEBEL A, GAMAS P (2008). EFD Is an ERF transcription factor involved in the control of nodule number and differentiation in Medicago truncatula. Plant Cell 20: 2696-2713.

WASSONAP, PELLERONE FI, MATHESIUSU(2006). Silencing the flavonoid pathway in Medicago truncatula inhibits root nodule formation and prevents auxin transport regulation by rhizobia. Plant Cell 18: 1617-1629. 
WRIGHTE, DIXON RA, WANG ZY (2006). Medicago truncatula transformation using cotyledon explants. In: Methods $\mathrm{Mol}$ Biol, K Wang, ed, Agrobacterium Protocols, Vol 343. Human Press, Totowa, NJ, pp 129-136.

YAMADA T, TAKAGI K, ISHIMOTO M (2012). Recent advances in soybean transformation and their application to molecular breeding and genomic analysis. Breed Sci 61: 480-494.
ZAMBREM, GOOSSENSA, CARDONAC, Van MONTAGUM, TERRYNN, ANGENON $G$ (2005). An efficient and reproducible Agrobacterium-mediated transformation systems for cultivated Phaseolus acutifolius (tepary bean). Theor Appl Genet 110: 914-924.

ZHOU X, CHANDRASEKHARAN MB, HALL TC (2004). High rooting frequency and functional analysis of GUS and GFP expression in transgenic Medicago truncatula A17. New Phytologist 162: 813-822.

\section{Further Related Reading, published previously in the Int. J. Dev. Biol.}

\section{Plant microRNAs and development}

Sara Jover-Gil, Héctor Candela and María-Rosa Ponce

Int. J. Dev. Biol. (2005) 49: 733-744

http://dx.doi.org/10.1387/ijdb.052015sj

\section{Historical perspectives on plant developmental biology}

Mieke Van Lijsebettens and Marc Van Montagu

Int. J. Dev. Biol. (2005) 49: 453-465

http://dx.doi.org/10.1387/ijdb.041927ml

Molecular-genetic approach to study plant growth and development M Van Montagu, M Van Lijsebettens and D Inzé

Int. J. Dev. Biol. (1996) 40: S49-S50

http://dx.doi.org/10.1387/ijdb.9087691

Mechanisms of the proliferation and differentiation of plant cells in cell culture systems H Fukuda, M Ito, M Sugiyama and A Komamine

Int. J. Dev. Biol. (1994) 38: 287-299

http://dx.doi.org/10.1387/ijdb.7981037

Plant protoplasts as genetic tool: selectable markers for developmental studies I Negrutiu, S Hinnisdaels, D Cammaerts, W Cherdshewasart, G Gharti-Chhetri and M Jacobs Int. J. Dev. Biol. (1992) 36: 73-84 http://dx.doi.org/10.1387/ijdb.1627478

5 yr ISI Impact Factor $(2011)=2.959$
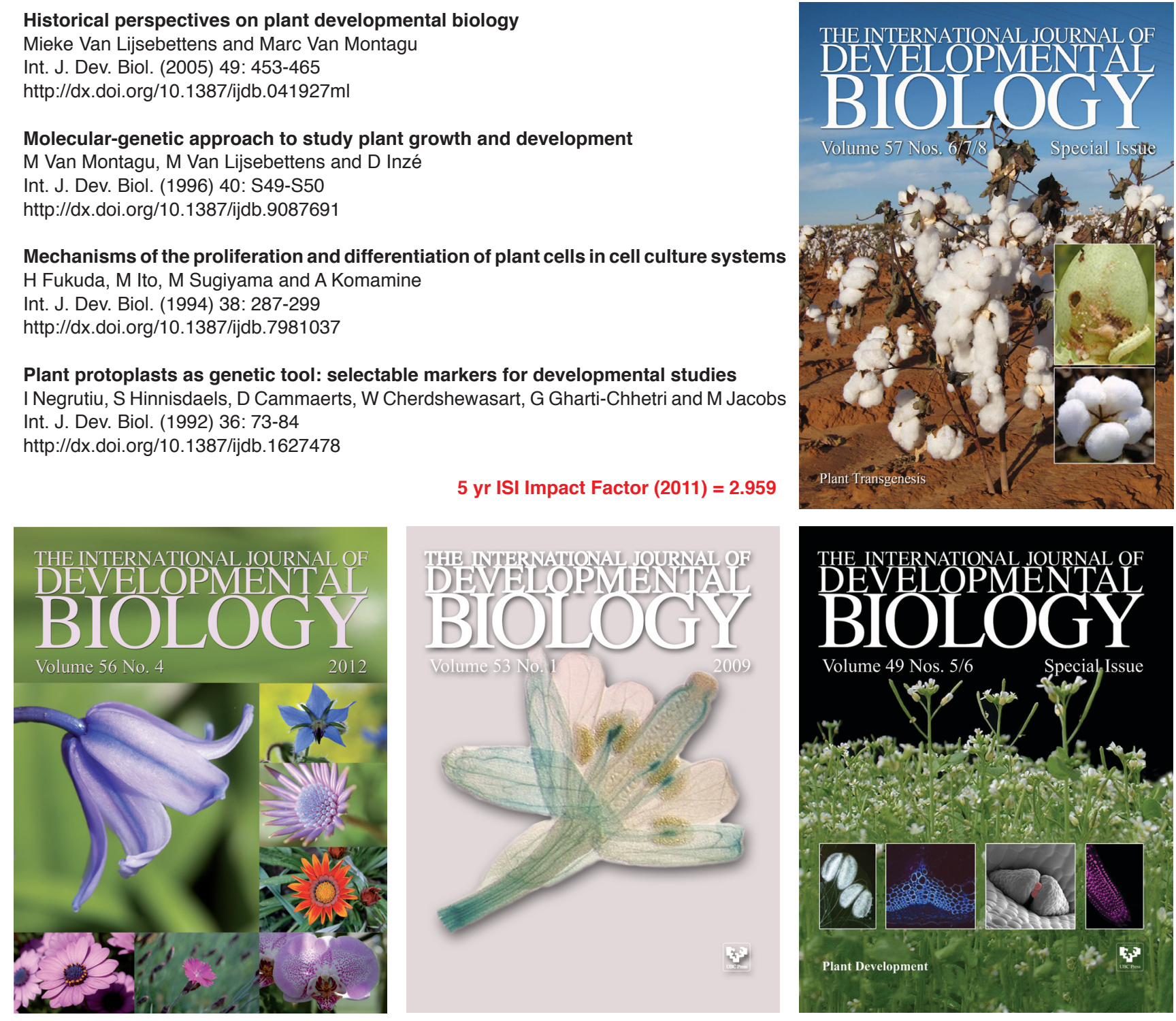